\title{
Effective Learning Skills and Labour Market: Implication for Community Development
}

\author{
M. O. Adedokun, (Ph.D) \\ Department of Adult Education and Community Development, \\ Faculty of Education, Ekiti State University, Ado-Ekiti, Nigeria
}

Doi: 10.36941/jesr-2019-0001

\begin{abstract}
Learning is a life-long process through which one uses acquired experiences to deal with new situations, develop new relationships and solve new problems. Learning in school must not be seen as being enough for solving everyday problem, hence there is need to learn and develop new skills that are practicable and can make people become employable in labour market. The problem of unemployment is all over the world now, however, those who had acquired necessary skills would find themselves employable in any situation. This study examines the effective skills that would make graduates of universities either employable or be self reliant in their own businesses. The researcher employed a descriptive research design of the survey type. A sample of 100 respondents was used for the study while a self designed questionnaire tagged "Effective skills for Labour Market and Implication for community Development" was used to gather the needed data. The data collected were analysed using descriptive and inferential statistics. One research question and three hypotheses were generated for the study and the results show among others that there is a significant relationship between effective labour skills and employability and that employability is significantly related to improved living which is an index of community development. It is, therefore, recommended that for graduates to be gainfully employed in a bid to contribute to the development of their persons as well as their communities, they must be armed with effective skills which would lead to their productivity in the labour market. Thereby, improving their living standards as well as being able to make their impact felt in their communities.
\end{abstract}

Keywords: labour market, Skills, active labour market, career education, employability

\section{Introduction}

Unemployment ravages the nooks and crannies of the world of today. This is not because jobs are not available in some instances but possibly because there are varied skill gaps between what learners acquired in schools and colleges and what employers are looking for in the labour market. Employers want well rounded people with a good mix of academic achievements, experience, common sense and life skills. Today, people need a bit of technological knowledge to excel in labour market since everything that is done in the world today involves technological innovation. This is not in connection with the fact that the world of work is undergoing rapid changes which needs rapid and quick adjustment to wider social and economic changes (Curriculum Council of Western Australia, 2001). It is therefore important for effective skills to be inbuilt in students' right from the high school level so as to get them prepared for labour market

\section{Literature Review}

Organization for Economic Cooperation and Development (OECD, 1993), recorded that there is global competition due to the effect of new technology and thus, the nature of work changes. This 
implies that people must move with time and arm themselves with skills of higher level than those of the past which could be termed obsolete. According to OECD, member states are to invest in human capital to enhance economic prosperity, employment opportunities and social cohesion (which is interpreted as income equality) as this will minimize income differences and improve employment opportunities for unemployed and underemployed workers. There is therefore, the need to recognize high level of knowledge and skills which are crucial to improving social cohesion that will generate both employment growth and national prosperity (OECD, 1993).

Hyslop-Margison and Welsh (2003) in their paper titled "Career education and labour market conditions: The Skill Gap Myth" addressed the issue of prevailing high technological knowledge based economy as a rationale supporting career education programme; contrasting it with labour realities dwelling on skill level and academic knowledge required to work in any sector of the economy; with the hope that increasing the knowledge and skills of students would make a difference in addressing the problem of unemployment. They anticipated in their study that skills required to work in job sectors should be targeted by career education. These authors found that there is the existence of a knowledge and skill gap which is usually assumed by career educational planners. Their conclusion was that there should be better career education reform put in place and one that will be practical oriented. The implication is that when students put into practice what they study, it makes them to be fully prepared for labour market.

Kluve (2016) in his review of the "Effectiveness of active labour market programmes" with focus on Latin America reiterated the fact that unemployment is a great challenge to all countries of the world both develop and developing. He states that the challenge is exacerbated by the fact that youth unemployment figures are typically twice the overall employment rate. He is of the opinion that policy makers worldwide, in view of the situation of unemployment put in place "effective programmes that can help the jobless find jobs and programmes that can increase workers' productivity and labour income" (P. 1).

Kluve (2016) describes active labour market programmes as interventions of labour market policy that welfare state uses with the intention of increasing the employment probability of job seekers thereby decreasing aggregate unemployment. The main aim of this, he says, is to increase the individual chances of programme participants with the aim of bringing about active support for labour market integration. Aver, Efendioglu and Leschke, (2008) suggest that embarking on active labour market programmes is likely to boost self-reliance as the culture of individual productivity could lead groups and individuals to poverty eradication. The programme should be targeted mostly at ghetto disadvantaged groups and the downtrodden of the society.

Active labour market programmes are of four types. These include job search assistance, labour market training, private sector incentives and public sector employments. Others identified by Aver et.al (2008) are: Subsidy programmes, enterprise start up programmes, compromising skill training and its funding among others.

Some other features of the active labour market programmes which should be included in educational programmes include - job security training, counselling, monitoring work practice, classroom work and basic skills training among others.

Asuquo and Agboola (2014) found in their study "Nigerian Universities outputs and their employers ability in the labour market in south-south, Nigeria" that employability of Nigerian university outputs based on the responses of their employers was significantly low and that the result was indifferent in spite of differences in respondents' sex, organization type, educational qualifications and age. This implies that contents of the study do not match employability conditions.

Olulube, Egbezor and Kpolovie (2008) adduced some reasons why graduates of universities are found unemployable. Some of these include: inadequate and obsolete infrastructure and poor library facilities. These have negative effects on the quality of teaching, learning and research and these account for lack of requisite skills needed by students when seeking employment.

Lack of competent teachers to carry out quality teaching that is related to labour market is another serious problem facing youths after school in getting adequate and relevant jobs.

Olulube and Egbezor (2008) describe employability as a measure of skills and knowledge which is based on ability, quality of instruction and type of organization or academic qualification. 
Pitan (2016) expressed concern over the current undergraduate unemployabilty linking the problem with the curriculum which is not producing expected results in graduates, hence, graduates lack the needed professional skills and life learning skills required for successful performance in labour market. She emphasized in her study the importance of producing employable graduates for 21st century jobs. This implies moving away from traditional skills into modern ones which are technologically enhanced and enabled. She recommended that learning experiences in universities should be ones that would translate into fulfilling active participation in labour markets.

Oliver, (2015) and Pitan (2015) felt strongly that there are signs that patterns of work are changing daily with new sections emerging which are technologically driven and being affected by globalization and demographic changes. These factors have led to gradual if not sudden reform of work force all over the world to which Nigerians must comply with, so as not to be found wanting in the world of work.

United Nations Educational Scientific and Cultural Organization (UNESCO) (2014), also noted that students and teachers are psychologically affected by negative physical and social conditions that may disrupt learning thereby affecting the quality of effective learning. It is, therefore, germane that an enabling learning environment be put in place for effective learning skills, skills that transcend the walls of the classroom. Such include, good laboratories that are adequately equipped from which students can put into practice their theoretical learning which will help them when they get to labour market. Well stocked libraries should be put in place not ones with obsolete books. Students are also expected to be equipped with skills for accessing e-libraries which is lacking in most institutions of higher learning in Nigeria. Where they are available, power outage is a big problem which should be given adequate priority in our institutions of learning in Nigeria.

\subsection{Effective Skills needed for Labour Market}

Several authors had identified various effective skills needed for labour market. The summary of the opinions of those authors is that whatever discipline a student pursues must not be in isolation of labour market needs and that theoretical knowledge should go with academic skills. Oluyombo (2016).

Bandura (1997) states strongly that self-efficacy which could be described as self-belief; that is, believing in one's self competence plays a strong role in job seeking. To him this skill could be instilled in would be -job seekers both at home and in school. To Bandura, this can be achieved through mastery experiences which are achievable through work experiences, social modelling and writing job applications. Students should be taken through the practical aspects of their studies while in school, field experiences should be emphatically embarked upon while in colleges as this will develop in them self-esteem and confidence which will carry them through labour market and life generally.

Pitan (2016) identified various skills needed for employability. Such include:

a. Academic Skills: This she refers to as subject or discipline skills and knowledge which are skills that provide basic foundation to get, keep and make progress in a job to achieve best results.

b. Generic Skills: These are skills that are applicable in many contexts. Such skills she says include core skills, key skills and other essential skills that are transferable.

c. Career education activities: These include work experiences to which students are exposed to during their study period, for example Teaching Practice Exercise, Industrial work experiences by engineering students and medical students are also exposed to the practical aspect of their profession before leaving college; all these are in a bid to gain necessary experience before getting to the labour market. Others as stated by her include:

- Participation in extra curriculum activities - this will aid students in socializing in the outside world.

- Reflection and assessment: Students should be moulded to reflect and assess the required learning experiences which lead to better performance when linked to skills needed in labour markets.

- Emotional intelligence is the capacity to recognize one's own feelings and those of 
others.

- Self-Awareness: This is the ability of individuals to assess their strengths and weaknesses; making prompt efforts to improve on identified weaknesses. These factors would help a person in search of job a greater opportunity than those who lack them.

Pitan in her study, recommended the components of employability to be incorporated into teaching while in colleges and that work study should be made mandatory for learners while career services should be put in place to bring out a complete learner.

Other factors that could aid employability include:

- Effective Communication Skills: Any job seeker must demonstrate that he can communicate well in varied situations depending on the job at hand.

- Ability to work independently without being supervised will help a job seeker as he/she could seek solutions to immediate problems and will be able to make decisions and be able to negotiate effectively without being supervised.

- Group and team working skills. These involve ability to participate and work with others in a positive, organized and collaborative way. Persons seeking job must be social and activity oriented. This is about meeting others with similar interest in a structural and dynamic way (Learning Skills, 2018)

Community development is about living well and attaining a balanced standard of living with the effect that poverty is eradicated. When people are jobless and lack initiative to embark on startup businesses due to lack of relevant skills; poverty is the end-result (Adedokun, 2011). However, when people are gainfully employed, the tendency to being ravaged by poverty is removed. Being gainfully employed calls for being innovative and use of initiative. These factors can be obtained through right knowledge acquisition both in school and home. Students must, therefore, be made to understand the impact of participation in school activities both indoor and outdoor activities. Opportunities must be provided for students in schools to learn through experience and they must be taught the importance of being involved in collective efforts so that they can gain confidence in their abilities and in their abilities to influence decisions that affect them. Thus, there is need, to in accordance with the factors encouraging community development:

- equip students with skills and competences which they otherwise do not have.

- realizing their existing skills and potentials.

- promoting in students self confidence.

- encouraging them to take responsibility for identifying and meeting their needs.

- encouraging students while in college to become involved in school activities, community activities and wider society in a fuller way. (Adedokun, 2011).

The above will enable students after school to seek ways of being employable, bridging skill gaps and thereby contributing not only to their own development but also to that of the community in which they live.

\section{Statement of the Problem}

It is observed that graduates of institutions of higher learning roam the streets of Nigeria in search of jobs. It is however, not clear whether lack of jobs is due to job unavailability or that students do not measure up to the standard needed by employers of labour. One tends to ask these questions:

Do graduates possess the needed skills required in labour market?

Are students equipped with necessary skills needed in labour market to prepare them for employability?.

Will being gainfully employed add values to communities where they domicile?

\section{Purpose of the Study}

The purpose of this study is to:

- examine whether graduates of higher institutions are equipped with needed skills for 
employability.

- determine whether effective skills would lead to employability and eventual contribution to personal development and community development.

\section{Research Question}

One research question was raised for the study;

- Are graduates of higher institutions of learning equipped with necessary effective skills for labour market with the resultant effect of having improved standard of living in their communities?

\section{Hypotheses}

Three hypotheses were generated for the study.

1. There is no significant relationship between effective skills for labour market and employability.

2. There is no significant relationship between employability and community development.

3. There is no significant relationship between effective skills for labour market and improved standard of living.

\section{Research Method}

The researcher made use of descriptive research of the survey type for the study. 100 respondents consisting of 60 respondents from the university of Ibadan and Ekiti State University, Ado-Ekiti; and 40 respondents from the Ibadan Polytechnic were used for the study.

A self-designed questionnaire covering effective skills for labour market and implication for community development was used to collect data for the study. The questionnaire was tagged "Effective Learning Skills for Labour Market: Implication for Community Development" (ELSLMICD). (Only 97 copies of questionnaire were retrieved from the respondents)

Data collected were analysed using descriptive and inferential statistics.

\subsection{Analysis of Results and Discussions}

The results and findings from the research are presented below with discussions

Research Question 1: Are graduates of higher institutions of learning equipped with effective skills for labour market?

Descriptive statistics of mean and standard deviation was used in the analysis of this questions as presented below.

Table 1: Effective labour skills for labour Market $(\mathrm{N}=97)$

\begin{tabular}{|c|l|c|c|}
\hline S/N & Items & Mean & Standard Deviation \\
\hline a. & Self confidence & 3.670 & .607 \\
\hline b. & Having the right mind set & 3.309 & .821 \\
\hline c. & Having the right degree in relevant subjects with good grades & 3.351 & .791 \\
\hline d. & Being open to new experience & 3.351 & 890 \\
\hline e. & Ability to communicate effectively & 3.691 & .618 \\
\hline f. & Ability to work independently & 3.402 & .759 \\
\hline g. & Ability to have team group working skills & 3.361 & .780 \\
\hline
\end{tabular}

The table above shows that the mean score and standard deviation of each item is a pointer of each skill in the world of employment. The table shows that having self confidence (mean $=3.670$; std .607), having the right mindset, (mean= 3.309, std .821), being open to new experiences (mean $=3.351$, std .791) and having the right degree in a relevant subject with good grades (mean= 


\subsection{1 , std .890 ) are all very germane to getting rewarding employment.}

The table also shows that there is need for further skills to be displayed in order to qualify for employability. Such include; ability to communicate effectively (mean 3.691, std .618), ability to work independently (mean $=3.402$, std .759 ) and ability to have both team and group working skills (mean= 3.361, std .780).

These skills are very relevant to bridging skill gaps as stated by Giovannozzi, Director of the Centre for Executive and Professional Education, Portland University (2019). To her; the demands on universities are changing, which means the approach universities need to take to meet the demand needs to evolve too. She submits that there are various skills gaps in the workforce which companies struggle to fill. Among other things calling for effective labour skills include descriptive technologies, automation and rapidly evolving business processes. All these according to Giovannozi (2019) have created new needs for knowledge and skills in workplaces; the implication of which is for colleges to move in line with the needs in companies and train graduates who would be skillful in filling the various available vacancies and those who would possess the ability to adapt and innovate. Adaptation and innovation are important in getting suitable employment. Having the right mind set, being self confident and being open to new experiences would guarantee adaptation and innovation which would lead to great achievement in the world of employment. Colleges of higher learning should thus, implement practices that will better equip learners in their ability to deliver leading edge, and in- demand knowledge.

Gerard-Shaw (2019) also believes that post secondary institutions should not lay much emphasis on subject matter education but on individual formation and growth. Education, in focusing the needs of the society should embark on a holistic approach to preparing graduates for life after college by instilling relevant skills in students while in school. According to Gerard-Shaw, student formation is a holistic system of education and preparation and he further states that it is an approach to be a successful person, a business leader and a good citizen.

Involved in student formation is helping them to be involved in critical analysis and decision making, how to act professionally and how to communicate effectively. All these are embedded in skills needed for employability.

Hypslop-Margison and Welsh (2003) in their study submit that skill gaps are causing labour market supply problems for industry and they opine that the skills required to work in job sectors should be targeted by career education. It is therefore, important to reshape students' attitudes to study so that these attitudes will comply with labour market needs.

Hypothesis1: There is no significant relationship between effective labour skills and employability.

Table 2: Relationship between effective labour skills and employability

\begin{tabular}{|c|c|c|c|c|c|}
\hline Items & $\mathrm{N}$ & Mean & $\mathrm{Sd}$ & $\mathrm{R}$ & $\mathrm{P}$ \\
\hline Labour skills & 97 & 24.134 & 2.528 & & \\
\hline & & & & .540 & 0.000 \\
\hline Employability & 97 & 13.330 & 3.511 & & \\
\hline
\end{tabular}

Significant $(P=0.000<0.05)$

Table 2 shows that there is a strong relationship between effective labour skills and employability. Effective labour skills: Mean- 24.134, sd. 2.528. Employability; mean: 13:330, sd. 3.511 with $r=$ .540. The result shows that there is a significant relationship between effective labour skills and employability.

In support the above result Rodicio (2019) believes that when partnership is enhanced with local employers, it would reveal the skill gap myth and this will pave way for innovative curricula that make students to be prepared for future jobs ,thus being enabled to fill the skill gaps.

Employability is a lifelong, continuous process of acquiring experience and new knowledge. There is, therefore, the need for the skills of individuals to be enhanced not only to obtain employment in labour market but to maintain learning which is an ongoing exercise which will lead to the maintenance of skills and learning of new ones. 
In support of the relationship between labour skills and employability, International Labour Organization (ILO) (2019) makes it clear that education is germane to getting decent jobs and that lifelong learning is crucial in other to keep up pace with technology changes and the skills needed for active labour market. When people develop their skills, they become employable. To ILO, skill development is the first step towards sustainable development which is key to the development of communities and nations at large.

Kluve (2016) in his review of the effectiveness of active labour market programme with a focus on Latin America and Caribbean, concludes that effective programmes that can help the jobless find job and programmes that can increase workers productivity and income be embarked upon. This in essence shows the relationship between effective labour skills and employability. When labour skills are becoming redundant, efforts must be made to create programme that can lead to new skills which will attract employment. Stressing the relationship further ILC (2008) believes that skills development is important in addressing the challengers of meeting new technologies in the context of globalization.

Hypothesis 2: There is no significant relationship between employability and community development.

Table 3: Relationship between employability and community development.

\begin{tabular}{|l|c|c|c|c|c|}
\hline Items & $\mathrm{N}$ & Mean & $\mathrm{Sd}$ & $\mathrm{r}$ & $\mathrm{P}$ \\
\hline Employability & 97 & 13.329 & 2.527 & & \\
\hline & & & & .348 & 0.000 \\
\hline Community Development & 97 & 13.928 & 1.872 & & \\
\hline
\end{tabular}

(significant $P=0.000<0.05$ )

Table 3 shows that employability (with mean of 13.329 ,sd of 2.527, r. 348 ) is significantly related to community development (which has a mean of $13.928, \mathrm{sd}=1.872, \mathrm{r}=.348$ ). The implication is that when graduates of universities acquire needed skills that will make job readily available for them, the likelihood is high that they are able to contribute not only to their personal development but also to their immediate communities and the nation as a whole as they would have voice in decision making that affects them in their communities..

Hypotheses 3: There is no significant relationship between effective labour skills and improved standard of living.

Table 4: Relationship between Effective Labour Skills and Improved Standard of Living.

\begin{tabular}{|l|c|c|c|c|c|}
\hline Items & $\mathrm{N}$ & Mean & $\mathrm{Sd}$ & $\mathrm{r}$ & $\mathrm{P}$ \\
\hline Effective Labour Skills & 97 & 24.134 & 3.511 & & \\
\hline & & & & .531 & 0.000 \\
\hline Improved Standard of Living & 97 & 13.928 & 1.872 & & \\
\hline
\end{tabular}

Table 4 above shows that there is a significant relationship between effective labour skills and improved standard of living; with effective labour skills having a mean score of 24.134 , sd= 3.511 at $r=5.31$ and improved standard of living with mean of 13.928 , $s d=1.872$ and $r=.531$ and significant at 0.000 . This implies that when effective labour skills are put to use in the process of employment, people obtain more knowledge and skills which will not only help in other daily job performance but help them in scaling up their standard of living.

In support of the findings in table 4, the International Labour Conference,(ILC) $97^{\text {th }}$ session 2008, Report V, states that skills development is central to improving productivity. In turn, productivity is an important source of improved living standards and growth. The document further states that the effective skills development systems which connect education to technical training to labour market entry and labour market to workplace and lifelong learning can help countries sustain productivity (n.p). With high level of productivity, the standard of living of individuals is raised. The standard of living is measured by things such as income and employment opportunities. Measuring 
standard of living will also involve poverty level and life expectancy among others. When people are employed, poverty is reduced to the barest minimum and people can enjoy a level of health service, education and other things that make life easier. Fontinelle (2019) listed other factors associated with the standard of living to include: class disparity, poverty rate, affordable access to quality health care, quality and availability of education and safety among others. With employability, poverty rate will be reduced, gaps between the rich and the poor will be bridged, good health could be ensured as people would have the means of accessing health care services and thereby, enjoy a better standard of living. The improved standard of living is however, predicated on conducive conditions in work places. These can be, when workers have necessary skills with which they can be gainfully employed. With necessary skills for gainful and rewarding employment, people are free from poverty, discrimination and they have the right to equal pay and work. They will also enjoy human dignity and right for equal treatment. This will lead to bridging the gap between the rich and the poor and make them contribute to the development of their communities

\section{Conclusion}

From the various authors and documents reviewed, it is clear that for graduates to be employed into labour markets, there is a great need for them to be imbued with effective skills; skills that are technologically oriented that will stand them out and tall when then there is need for people to be employed in this competitive era. When learners are equipped with effective learning skiils, they could either get good and rewarding job which would lead to their raised standard of living and having the right skills for labour market could make graduates of universities to be involved in a start-up business so as to be self reliant as relying on government to provide job for all is becoming difficult by the day. It is, therefore, important for students to have the needed mindset with effective skills to set up their own businesses so that they could hire labour to diminish poverty level in their communities and the nation.

\section{Recommendations}

The following are recommended based on the findings of the study:

Policy makers on education should revisit the curriculum to make it more practical so as to help graduates secure good jobs when they leave school. There should be a kind of synergy between the school work and the outside labour market

Teachers should aspire to teach the skills needed by graduates when they leave school with passion to these students who would face the ordeal of job search.

Career education should be inculcated into school programme so as to lead students in the right direction in the process of choosing their course of study for eventual job market. Counselors should, therefore, not abandon their work of counseling the students with career education put in place.

Attitudes of students should be reshaped to practicing these needed effective skills that would qualify them for labour market while still in the university

A system should be put in place by the government whereby partnership with local employers would be enhanced.

\section{Implication for Community development}

For individuals within any community to live above poverty level, there is need for developing in them adequate skills that would make them function well in the world of works. It is not enough for students to pass through university but the university must also pass through them, this will be the essence of being employable while in the labour market as a lot of skills would have been built in them while in school. The Universities, thus, should be a preparatory ground for acquisition of skills for labour market as well as for self reliance. When relevant skills are acquired, graduates of universities will not be engaged in criminal activities due to idleness but would have been equipped with essential skills that will make them contribute to their personal development as well as the development of their communities. 


\section{Acknowledgments}

Appreciation to all authors consulted and cited.

\section{References}

Adedokun M.O. (2011). A handwork of community development. Lagos, Honey-Crown Educational Publishers.

Asuquo, A.A. and Agboola, B.M. (2014). "Nigeria Universities outputs and their Employability in the labour market". American Journal of Educational Research 2(12) 1244-1249.

Aver, P., Efendioglu, Very and Leschke, J. (2008). Active Labour market policies around the world: Coping with the consequences of globalization; 2nd Edition, Geneva, ILO.

Bandura, A. (1997) Self efficacy. The exercise of central. New York NY: WH. freeman.

Curriculum Council of Western Australia (2001). Work Studies. (Online) Available http://www.curriculum.wa.edu.au/pages/subj/subj686.htm

Fontinelle, A. (2019). Standard of living Vs Quality of life: What difference? (Online) Available https://www.investopedia.com/articles/financial-theory/08/standard-of-living-quality-of-life.asp (Accessed April 2, 2019).

Gerard-Shaw, P. (2019). Expanding beyond the classroom: Adapting a holistic focus on student formation. The Evolution: A destiny Solution illumination. (Online) Available https://evolution.com/attractingstudents/todays-learner/expanding-beyond-the-classroom-adapting-a-holistic-focus-on-studentformation/utm-campaign=hs-email_\&utm_mrdium=email\&utm_content=713 290 24. (April 1, 2019).

Giovannozzi, M. (2019). Eight strategies to help universities stay relevant and shrink skills gaps. (Online) Available http://evolution.com/programming/credentials/eight-strategies-to-help-universities-stay-relevantand-shrink-skills-gaps/? (Accessed- April 1, 2019) - The Evolution- a destiny solution Illuminations. Non Traditional Education Newspaper.

Hyslop-Margison, E.J. and Welsh, B.H. (2003). "Career education and labour Market Conditions: The Skill Gap Myth". The Journal of Educational Thought 37(1) 5-21.

Hyslop-Margison, E.J. and Welsh, B.H. (2003). Career education and labour market conditions. "The Skill Gap Myth" The Journal of Educational Thought (JET) 37(1) 5-21.

ILC (2008). Conclusion on skills for improved productivity, employment growth and development: Geneva, ILO. International labour organization (2019): Skills and employability. (Online) Available http:www.ilo.org/globaltopics/dw4sd/themes/skills/large=en/index.htm (Accessed April 2, 2019).

Kluve, J. (2016). A review of the effectiveness of active labour market programmes with a focus in Latin America and the Caribbean. (Online) Available https://www.ilo.org/wcmsp5/grouos/publicedgreports/einst /documents/publications/wcms/459117.pdf (20/11/18).

Learning Skills (2019). (Online) Available https://www.skills.need.com/learning-skill.html. (Accessed 17-10-18).

Oliver, B-(2015). "Redefining graduate employability and work integrated learning: Proposals for effective higher education in disrupted economies" Journal of Teaching and Learning for Graduate Employability 6(1) 56-65.

Olulube, N.P. and Egbezor, D.E. (2008). 'Educational technology and flexible education in Nigeria: Meeting the need for effective teacher education' in S. Marshal, W. ,Kinthia and W. Taylor (eds) Bridging the Knowledge divide: Educational technology for Development. Charlotte, N.C, Information Age Publishing.

Olulube, N.P., Egbezor, D.E. and Kpolovie, P.J. (2008) Education, politics and teacher education programmes: Meeting the Millennium Development Goals: Journal of Teacher Education for Sustainability 9(1) 21-34.

Organisation for Economic Cooperation and Development (OECD) (1997). Prepared for life? Paris, Organization for Economic Cooperation and Development

Pitan, O.S. (2015). An assessment of generic skills demand in five sectors of Nigerian labour market. Public and Municipal Finance 4(1) 28-36.

Pitan, O.S. (2016) "Towards enhancing university graduates employability in Nigeria" Journal of Sociology Anthropology . 7(1) 1-11.

Rodicio, L (2019). Partnering with an industry giant to fill skills gaps and support job readiness. The Evolution: A destiny solution illumination. (Online) Available https://info.destinysolutions.com/e2t/c/w5-pm (March 25, 2019).

United Nations Educational and Scientific and Cultural Organization (UNESCO) (2014). Education learning environment. (Online) Available http://www.unesco.org/new/en/educational/themes/strengheningeducation-systems/quality-famework/core-resource/learning-environments/ (April 25, 2019). 